\title{
CORRIGENDUM
}

\section{MORALITY, LAW AND CONFLICTING REASONS FOR ACTION}

\author{
P. CANE
}

doi:10.1017/S0008197312000207, Published by Cambridge University Press, March 2012.

The sentence punctuation and division in the opening paragraph of this paper is incorrect for which the author apologises.

The sentence should read: "This article is an expanded version of the $26^{\text {th }}$ Maccabaean Lecture in Jurisprudence delivered at the British Academy on 15 November 2011. That year marked the fiftieth anniversary of the publication ..."

\section{REFERENCE}

P. Cane (2012). Morality, Law and Conflicting Reasons for Action. CLJ, Volume 71, Part I. doi:10.1017/S0008197312000207 